\title{
Anemia of Prematurity
}

National Cancer Institute

\section{Source}

National Cancer Institute. Anemia of Prematurity. NCI Thesaurus. Code C97167.

A blood disorder characterized by low hemoglobin levels in premature neonates that usually spontaneously resolves within 3-6 months post birth. A combination of factors including the transition from the liver to the bone marrow for erythropoiesis in a neonate, blood loss experienced during delivery, the shortened life span of fetal blood cells, and an acclimation to a relatively hyperoxic environment outside the womb can predispose a neonate to this condition. 